\title{
Yield and Dry Matter Production of a Japanese Tomato 'Momotaro York' Are Improved by Grafting onto a Dutch Rootstock 'Maxifort'
}

\author{
Tadahisa Higashide*, Akimasa Nakano and Ken-ichiro Yasuba** \\ NARO Institute of Vegetable and Tea Science, Tsukuba 305-8666, Japan
}

To improve the yield of a Japanese tomato (Solanum lycopersicum) cultivar and determine how fruit yield changes as a result of grafting, we investigated the effects of a Dutch rootstock ['Maxifort' (S. lycopersicum $\times$ S. habrochaites): Mx] on the dry matter (DM) production and fruit yield of Dutch and Japanese cultivars. The Japanese cultivar ('Momotaro York': My) grafted onto Mx (My/Mx: scion/rootstock) had significantly higher fresh and dry weights of fruits per unit area than My/My. Fruit fresh weight yield per unit area was highly correlated with fruit dry weight $(\mathrm{DW})$ yield $(r=0.96-0.97, P<0.001)$, and DW yield was significantly correlated with total aboveground DM $(r=0.71-0.96, P<0.001)$ and with DM allocation to the fruits $(r=0.52-0.75, P<0.01)$. Total aboveground DM (TDM) was significantly and highly correlated with light-use efficiency $(r=0.98, P<0.001)$. However, there was no significant correlation between light-use efficiency and the maximum photosynthetic rate, stomatal conductance, or the light-extinction coefficient. Although stomatal conductance significantly $(P<0.05)$ differed between the rootstocks at 57 and 119 days after transplanting (DAT), there was no significant difference in the maximum photosynthetic rate between the scion/rootstock combinations at 57 and 119 DAT. These results indicated that the fruit yield of My could be improved by grafting onto Mx, and that the increases in yield and TDM were mainly determined by the increase in light-use efficiency.

Key Words: grafting, light-use efficiency, photosynthetic rate, rootstock, stomatal conductance.

\section{Introduction}

In Japan, tomato (Solanum lycopersicum) is the most important vegetable crop and has had the highest total production rate for many years (Ministry of Agriculture Forestry and Fisheries, 2007). However, the yield of greenhouse tomatoes has not increased since the 1980s, remaining well below $30 \mathrm{~kg} \cdot \mathrm{m}^{-2}$ per year (Ministry of Agriculture Forestry and Fisheries, 2007). In contrast, the yield of greenhouse tomatoes in the Netherlands doubled from ca. $30 \mathrm{~kg} \cdot \mathrm{m}^{-2}$ per year in the $1980 \mathrm{~s}$ to $\mathrm{ca} .60 \mathrm{~kg} \cdot \mathrm{m}^{-2}$ per year in 2005 (Kwantitatieve Informatie voor de Glastuinbouw, 2005). Higashide and Heuvelink (2009) investigated the causes of the Dutch yield improvements by breeding and showed that the yield increase during the past 50 years was due to an increase in total aboveground dry matter (DM) production related to high light-use efficiency (LUE). Recently, to determine the cause of the low tomato yield in Japan and to improve

Received; January 10, 2013. Accepted; February 12, 2014.

First Published Online in J-STAGE on May 9, 2014.

* Corresponding author (E-mail: ton@affrc.go.jp).

** Present address: Faculty of Agriculture, Okayama University, Okayama 700-8530, Japan. the yield, the "Super Horticulture Project" was launched (Japan Greenhouse Horticulture Association, 2006). Higashide et al. (2012) reported that the fruit yield of the Japanese tomato cultivar 'Momotaro' (released in 1985) was lower than that of older cultivars but that the soluble solids content in fruits of 'Momotaro'-type cultivars were higher than those of the older Japanese cultivars for a given DM content of fruit. They concluded that Japanese breeders may have focused on aspects of fruit quality, such as soluble solids, rather than on yield, since Japanese consumers and retailers have demanded improvements in fruit taste more strongly than yield improvements. One goal of the present study was to improve the yield of Japanese tomato cultivars while retaining high soluble solids in the fruits.

Grafting is a popular technique in Japan for avoiding soil-borne diseases such as bacterial wilt. In addition to improving disease resistance, many authors have reported that grafting influenced tomato yield and that the yield increase depended on the choice of rootstock (Khah et al., 2006; Mohammed et al., 2009; Sada, 1981; Turkmen et al., 2010). Masuda and Furusawa (1991) reported an improvement in tomato fruit quality using Japanese standard rootstocks, but no increase in the fruit 
yield. Flores et al. (2010) and Savvas et al. (2011) also reported improvements in tomato yield and soluble solids by using salt-tolerant rootstocks under saline conditions. In contrast, Fan et al. (2011) reported no influence of Chinese and American rootstocks on yield under saline conditions. Despite these many reports of the influence of grafting on tomato yield, the mechanisms responsible for this influence have not been determined. Although grafting is popular in vegetable production in Japan, it is less popular in hydroponic culture because growers believe that soil-borne diseases occur less-frequently in hydroponics. To determine the importance of a root system, we attempted to improve the yield of Japanese cultivars by grafting them onto a Dutch rootstock.

The leaf photosynthetic rate influences tomato yield. Gosiewski et al. (1982) reported that a high photosynthetic rate in tomato leaves was determined by high specific leaf weight (thick leaves) and a high leaf weight ratio, but the photosynthetic rate was not influenced by stomatal conductance. In contrast, stomatal conductance affects gas exchange in leaves, and may consequently affect the photosynthetic rate. The photosynthetic rate of Dutch tomato cultivars was higher in cultivars with high stomatal conductance than in those with low conductance (Higashide and Heuvelink, 2009). This suggested that the increase in stomatal conductance might increase gas exchange and thereby increase the photosynthetic rate. The leaf photosynthetic rate and translocation of photoassimilate may be influenced by the plant's sinksource ratio (Tanaka and Fujita, 1972), by the rhizosphere environment (Shishido and Kumakura, 1994), and by root activity (Jiang et al., 1994). Arp (1991) reported downregulation of the photosynthetic rate in response to photoassimilate accumulation in the leaves of $\mathrm{C}_{3}$ plants. Similarly, Hojo and Park (1971) investigated changes in the relationship between photosynthetic rates and the sink-source ratio in grafted sweet potato, and found that the leaf photosynthetic rate increased with increased root weight. A subsequent study confirmed that the photosynthetic rate of the sweet potato decreased earlier in plants with rootstocks that produced low sink strength (Kubota et al., 1993). DM allocation to the roots was lower in the tomato seedlings of 3 Japanese cultivars than in seedlings of several Dutch cultivars (Higashide, unpublished data). Based on these results, we tested whether Japanese tomato cultivars had lower leaf photosynthetic rates, and whether the photosynthetic rate could be improved by grafting a Japanese scion onto a Dutch rootstock.

In the present study, we investigated the effects of a Dutch interspecies rootstock 'Maxifort' (S. lycopersicum $\times S$. habrochaites) on DM production and fruit yield with the goal of improving the yield of Japanese tomato cultivars. To determine the causes of yield changes caused by different rootstocks, we also investigated the growth and photosynthetic characteristics of the grafted plants and the yield components of the Dutch and Japanese cultivars and rootstocks.

\section{Materials and Methods}

We compared self-grafted Dutch and Japanese tomato cultivars and those cultivars that were grafted onto rootstock from the other nation in a short-term experiment. As scion cultivars, we used 'Gourmet' (G; De Ruiter Vegetable Seeds, Bergschenhoek, the Netherlands) and 'Momotaro York' (My; Takii Seeds, Kyoto, Japan). Both are indeterminate types, but they bear medium and large round fruits, respectively. Both were self-grafted (G/G; My/My: scion/rootstock) and grafted onto the Dutch interspecies rootstock 'Maxifort' (Mx; De Ruiter Vegetable Seeds) $(\mathrm{G} / \mathrm{Mx} ; \mathrm{My} / \mathrm{Mx})$ and the Japanese rootstock 'Spike 23' (S; S. lycopersicum; Aisan Seeds, Aichi, Japan) (G/S; My/S).

We sowed seeds of G, My, Mx, and S as rootstocks in seed trays filled with a nursery soil on 12 October 2010, and 2 days later, we sowed the seeds of $\mathrm{G}$ and $\mathrm{My}$ as scions. The trays were placed in a seedling growth chamber (Seedling Terrace; MKV Dream, Tokyo, Japan). The plants were fertilized every 2 days from below using a commercial nutrient solution (High-Tempo; Sumitomo Chemicals, Tokyo, Japan); the solution consisted of $10.7 \mathrm{mM} \mathrm{NO}_{3}^{-}, 6.3 \mathrm{mM} \mathrm{K}^{+}, 5.4 \mathrm{mM} \mathrm{Ca}^{2+}, 1.9 \mathrm{mM}$ $\mathrm{Mg}^{2+}, 2.4 \mathrm{mM} \mathrm{H}{ }_{2} \mathrm{PO}_{4}^{-}, 3.8 \mathrm{mg} \cdot \mathrm{L}^{-1} \mathrm{Fe}, 0.38 \mathrm{mg} \cdot \mathrm{L}^{-1} \mathrm{Mn}$, $0.26 \mathrm{mg} \cdot \mathrm{L}^{-1} \mathrm{~B}, 0.15 \mathrm{mg} \cdot \mathrm{L}^{-1} \mathrm{Zn}, 0.05 \mathrm{mg} \cdot \mathrm{L}^{-1} \mathrm{Cu}$, and $0.07 \mathrm{mg} \cdot \mathrm{L}^{-1} \mathrm{Mo}$, adjusted to an electrical conductivity of $1.8 \mathrm{dS} \cdot \mathrm{m}^{-1}$. The seedlings were illuminated with fluorescent lamps using a 16-h day length and a photosynthetic photon flux density $(P P F D)$ of $397 \pm 39 \mu \mathrm{mol} \cdot \mathrm{m}^{-2} \cdot \mathrm{s}^{-1}$ $\left(\right.$ mean $\pm \mathrm{SD}$ ), and were grown at $900 \mu \mathrm{mol} \cdot \mathrm{mol}^{-1} \cdot \mathrm{CO}_{2}$, which is the standard $\mathrm{CO}_{2}$ concentration used in Japan to prepare seedlings using an artificial lighting chamber, and air temperatures of 23 and $17^{\circ} \mathrm{C}$ (day and night).

On 28 and 29 October 2010, the seedlings of G and My were self-grafted or grafted onto the rootstock cultivars (Mx and $\mathrm{S}$ ), and 7 days later, the seedlings were transplanted into rockwool cubes. We then compared the 6 scion/rootstock combinations $(\mathrm{G} / \mathrm{Mx}, \mathrm{G} / \mathrm{S}, \mathrm{G} / \mathrm{G}$, $\mathrm{My} / \mathrm{Mx}, \mathrm{My} / \mathrm{S}$, and $\mathrm{My} / \mathrm{My}$ ) from 16 November 2010 to 22 March 2011. On 16 November 2010, the plants were transplanted into 7 rows of a rockwool system, at 60 plants per row in a greenhouse compartment $(14 \times$ $12 \mathrm{~m}$ ) at the National Agriculture and Food Research Organization, Institute of Vegetable and Tea Science, Taketoyo, Aichi, Japan. We supplied the plants with a commercial nutrient solution (Otsuka-A; Otsuka AgriTechno, Tokyo, Japan), which consisted of $9.3 \mathrm{mM}$ $\mathrm{NO}_{3}^{-}, 4.3 \mathrm{mM} \mathrm{K}^{+}, 4.1 \mathrm{mM} \mathrm{Ca}^{2+}, 1.5 \mathrm{mM} \mathrm{Mg}^{2+}, 0.9 \mathrm{mM}$ $\mathrm{H}_{2} \mathrm{PO}_{4}^{-}, 2.7 \mathrm{mg} \cdot \mathrm{L}^{-1} \mathrm{Fe}, 1.2 \mathrm{mg} \cdot \mathrm{L}^{-1} \mathrm{Mn}, 0.51 \mathrm{mg} \cdot \mathrm{L}^{-1} \mathrm{~B}$, $0.09 \mathrm{mg} \cdot \mathrm{L}^{-1} \mathrm{Zn}, 0.03 \mathrm{mg} \cdot \mathrm{L}^{-1} \mathrm{Cu}$, and $0.03 \mathrm{mg} \cdot \mathrm{L}^{-1} \mathrm{Mo}$, adjusted to an electrical conductivity of 1.2 to $2.5 \mathrm{dS} \cdot \mathrm{m}^{-1}$ as plants grew. The interval of nutrient solution supply was controlled based on outdoor solar radiation. The daily drain percentage was maintained at $20 \%$ to $30 \%$ of the total supply of nutrient solution. The drainage was not re-used for cultivation. The temperatures at which 
ventilation and heating started were set at 25 and $13^{\circ} \mathrm{C}$, respectively. Although the daily maximum air temperatures remained ca. $25-27^{\circ} \mathrm{C}$ on clear days during the experimental period, the daily average air temperatures decreased from ca. $17^{\circ} \mathrm{C}$ at transplanting to ca. $14^{\circ} \mathrm{C}$ in January, and then increased to ca. $18^{\circ} \mathrm{C}$ at the end of February (Fig. 1). The daily cumulative photosynthetically active radiation $(P A R)$ fluctuated daily from ca. 3 at transplanting to ca. $2 \mathrm{MJ} \cdot \mathrm{m}^{-2}$ in late December, and then increased to $6 \mathrm{MJ} \cdot \mathrm{m}^{-2}$ in March (Fig. 1). Planting density was 2.5 plants per $\mathrm{m}^{2}$. Flowers were pollinated by bumblebees. Plants were trained and their leaves were pruned according to the standard Dutch practice. The pruned axillary buds and leaves were excluded from the measurement. The experiment was a complete randomized block design with 3 blocks. Each block contained 2 double rows and a border row on each side of the blocks. In the double rows, the spacing was $60 \mathrm{~cm}$ between adjacent rows, $190 \mathrm{~cm}$ between adjacent double rows, with 20 plants per scion/rootstock combination planted per block, 3 scion/rootstock combinations per double row. We planted 10 plants per scion/rootstock combination in the border rows and did not include these plants in our measurements. We harvested all mature fruits from 8 plants per scion/rootstock combination in each block 3 times per week and measured their fresh and dry weights. We also measured leaf (leaf blade + petiole) area using an LI-3100C leaf-area meter (LI-COR, Lincoln, NE, USA) and the fresh and dry weights of leaves, stems, and all fruits of 2 or 4 plants destructively sampled per scion/ rootstock combination per block at 63,92, and 126 days after transplanting (DAT). Mature and immature fruits were measured separately. To avoid the effects of this sampling on the remaining plants and on their light interception, we used 2 plants and 2 adjacent guard plants per scion/rootstock combination per block, in each measurement in the first 2 destructive samplings.

The individual-leaf photosynthetic rate and stomatal conductance were measured twice, at 57 and 119 DAT, with a portable photosynthesis system (LI-6400; LI-COR) at a photosynthetic photon flux density $(P P F D)$ of $1500 \mu \mathrm{mol} \cdot \mathrm{m}^{-2} \cdot \mathrm{s}^{-1}$ and $1000 \mu \mathrm{mol} \cdot \mathrm{mol}^{-1}$

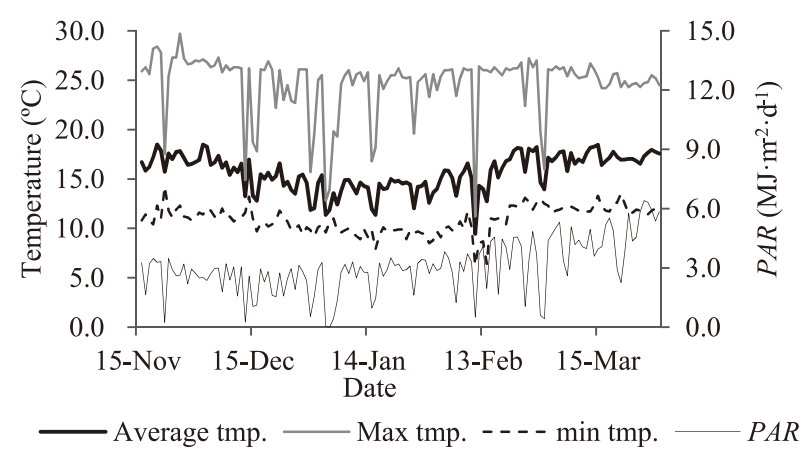

Fig. 1. Daily average, maximum, and minimum temperatures and cumulative photosynthetically active radiation $(P A R)$ in the greenhouse during the experiment.
$\mathrm{CO}_{2}$, respectively. The measurements were conducted between 11:00 and 14:30 using 2 mature leaves (without shading by any other leaves) of 3rd to 5th leaves from the top of 2 plants in each scion/rootstock combination per block. Temperatures (mean $\pm \mathrm{SD}$ ) during the measurements at 57 and 119 DAT were $28.0 \pm 1.4$ and 28.2 $\pm 2.2^{\circ} \mathrm{C}$, respectively, Light extinction within the plant canopy can be described using the following equation (Monsi and Saeki, 2005):

$$
I=I_{0} \mathrm{e}^{-k L}
$$

where $I$ represents the light intensity at a given point in the plant canopy, $I_{0}$ represents the light intensity above the canopy, $k$ represents the light-extinction coefficient, and $L$ represents the cumulative leaf area index (LAI) at that point in the canopy. To obtain the light-extinction coefficient for each scion/rootstock combination, we measured PPFD using a 1-m-long PPFD sensor (LI191SA; LI-COR) at 6 different heights within the closed plant canopy at 65 DAT (when canopy closure occurred): LAI ranged from 3.2 to 4.4 , and plant height ranged from 170 to $210 \mathrm{~cm}$. $P P F D$ above the plant canopy was also measured with a PPFD sensor (LI-190SA; LI-COR) and recorded using a datalogger (NR-600; Keyence, Tokyo, Japan). The individual-leaf area of each scion/rootstock combination was obtained using the following regression equation:

$$
A_{1}=a L_{1} W_{1}
$$

where $A_{1}$ represents the individual-leaf area $\left(\mathrm{cm}^{2}\right), a$ represents a proportionality factor for each scion cultivar $(0.40, \mathrm{G} ; 0.34, \mathrm{My}), L_{1}$ represents the leaf length $(\mathrm{cm})$, and $W_{1}$ represents the leaf width $(\mathrm{cm})$. The linear regression equations $\left(R^{2}=0.76\right.$ for $\mathrm{G}$ and 0.90 for $\mathrm{My}, P<$ 0.001 ) were obtained by destructive sampling of 6 plants (72 leaves) at 62 DAT. The cumulative LAI at each of the 6 heights within the canopy was calculated from the individual-leaf area and the number of leaves at that height. The light-extinction coefficient was obtained as the slope of a logarithmic regression of PPFD against cumulative LAI at the 6 heights. LUE was calculated as the slope of a linear regression of the total cumulative DM production as a function of the integrated interception of PAR on the 3 sample dates. Greenhouse transmissivity and the fraction of $P A R$ were assumed to be $60 \%$ and $50 \%$ of global radiation, respectively (Kurata, 1994; Ohtani, 1997). Daily PAR intercepted by the plants of each scion/rootstock combination was calculated from LAI and the corresponding light-extinction coefficient. Effects of the scion, rootstock, and their interaction on the growth characteristics of combinations were analyzed by two-way ANOVA. Pearson's correlations among the various yield components were also investigated based on the report by Higashide and Heuvelink (2009).

\section{Results}

Fresh fruit yield was significantly $(P<0.001)$ higher 
in the combination with $\mathrm{G}$ scions $(\mathrm{G} / \mathrm{Mx}, \mathrm{G} / \mathrm{S}$, and $\mathrm{G} / \mathrm{G})$ than in those with My scions (My/Mx, My/S, and My/My; Fig. 2). Among the combinations with $\mathrm{G}$ scions, $\mathrm{G} / \mathrm{Mx}$ was $23 \%$ higher in fruit yield than $\mathrm{G} / \mathrm{S}(P<$ 0.05). Among the combinations with My scions, $\mathrm{My} / \mathrm{Mx}$ was $32 \%$ higher in fruit yield than My/My $(P<0.05)$. There was no significant interaction of scion $\times$ rootstock on the fresh fruit yield. Similarly, fruit dry weight (DW) per area was significantly $(P<0.001)$ higher in the combination with $\mathrm{G}$ scions than in those with My scions (Fig. 3). Among G scions, G/Mx was also $22 \%$ higher in fruit DW per unit area than $\mathrm{G} / \mathrm{S}(P<0.05)$. Among My scions, My/Mx was $31 \%$ higher in fruit DW yield than My/My $(P<0.05)$. Although $\mathrm{G}$ scions were significantly $(P<0.001)$ lower in the fruit DM content than My sci-

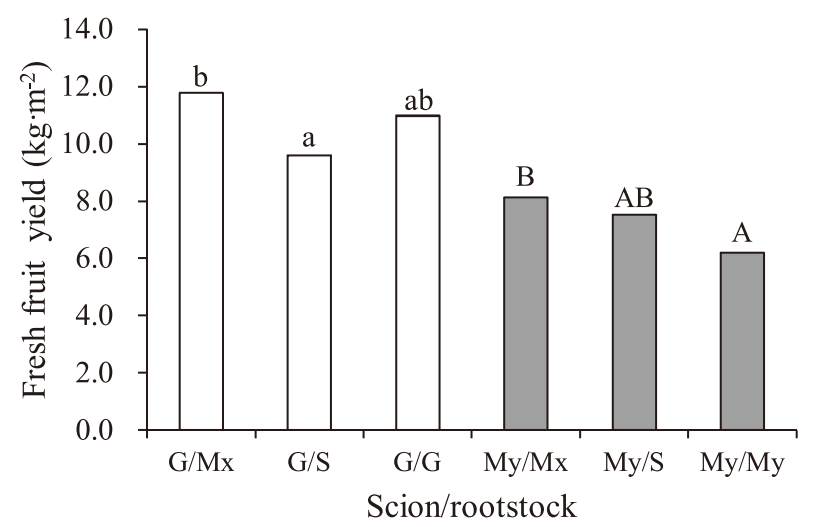

Fig. 2. Fresh fruit yield in plants reciprocally grafted between Dutch and Japanese cultivars at 126 days after transplanting. Different letters differ significantly within the same scion-cultivar $(P<$ $0.05 ; \mathrm{n}=12$; by Bonferroni post-hoc test). $\mathrm{G}$ and $\mathrm{Mx}$ indicate 'Gourmet' and 'Maxifort' of Dutch cultivars, respectively; My and S indicate 'Momotaro York' and 'Spike 23' of Japanese cultivars, respectively. ons, there was no significant difference in the fruit DM content among the rootstocks (/Mx, S, and self-grafts) for each scion. There was also no significant interaction of scion $\times$ rootstock on both fruit DW yield and fruit DM content. No significant difference was observed in fresh weight per fruit among the rootstocks for each scion cultivar (data not shown).

The maximum photosynthetic rate of individual leaves did not differ significantly between the scions, rootstocks or the interaction of scion $\times$ rootstock at 57 or 119 DAT (Table 1). As there were significant differences among the scions, the stomatal conductance in $\mathrm{G}$ scions was significantly higher $(P<0.001)$ at 57 DAT but lower $(P$ $<0.05)$ at 119 DAT than in My scions. The conductance significantly differed between the rootstocks at 57 and

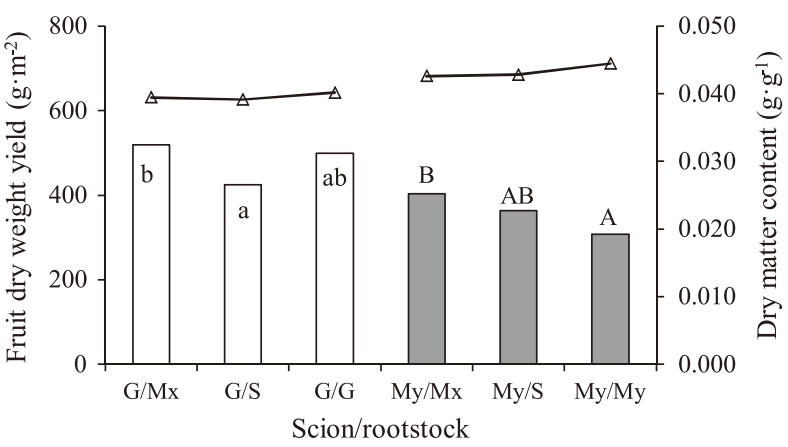

Fig. 3. Fruit dry weight yield (bars) and the dry matter content (lines) of mature fruits in tomato plants reciprocally grafted between Dutch and Japanese cultivars at 126 days after transplanting. Different letters differ significantly within the same scioncultivar $(P<0.05 ; \mathrm{n}=12$; by Bonferroni post-hoc test). $\mathrm{G}$ and $\mathrm{Mx}$ indicate 'Gourmet' and 'Maxifort' of Dutch cultivars, respectively; My and S indicate 'Momotaro York' and 'Spike 23' of Japanese cultivars, respectively. Immature and mature fruits were used for the measurement of fruit dry weight yield.

Table 1. Maximum photosynthetic rate and stomatal conductance of individual leaves of Dutch and Japanese tomato cultivars with 3 different rootstocks at 57 and 119 days after transplanting (DAT).

\begin{tabular}{|c|c|c|c|c|c|}
\hline \multirow{2}{*}{\multicolumn{2}{|c|}{ Scion/rootstock ${ }^{2}$}} & \multicolumn{2}{|c|}{$\begin{array}{l}\text { Maximum photosynthetic rate } \\
\left(\mu \mathrm{mol} \cdot \mathrm{m}^{-2} \cdot \mathrm{s}^{-1}\right)\end{array}$} & \multicolumn{2}{|c|}{$\begin{array}{l}\text { Stomatal conductance } \\
\left(\mathrm{mol} \cdot \mathrm{m}^{-2} \cdot \mathrm{s}^{-1}\right)\end{array}$} \\
\hline & & 57 DAT & 119 DAT & 57 DAT & 119 DAT \\
\hline \multicolumn{2}{|c|}{$\mathrm{G} / \mathrm{Mx}$} & 29 & 33 & $0.422 \mathrm{abc}^{\mathrm{w}}$ & $0.171 \mathrm{~b}$ \\
\hline \multicolumn{2}{|c|}{$\mathrm{G} / \mathrm{S}$} & 29 & 35 & $0.459 \mathrm{bc}$ & $0.181 \mathrm{~b}$ \\
\hline \multicolumn{2}{|c|}{$\mathrm{G} / \mathrm{G}$} & 29 & 35 & $0.514 \mathrm{c}$ & $0.162 \mathrm{~b}$ \\
\hline \multicolumn{2}{|c|}{$\mathrm{My} / \mathrm{Mx}$} & 25 & 34 & $0.364 \mathrm{ab}$ & $0.185 \mathrm{~b}$ \\
\hline \multicolumn{2}{|c|}{$\mathrm{My} / \mathrm{S}$} & 31 & 34 & $0.447 \mathrm{bc}$ & $0.129 \mathrm{a}$ \\
\hline \multicolumn{2}{|c|}{$\mathrm{My} / \mathrm{My}$} & 31 & 37 & $0.334 \mathrm{a}$ & $0.164 \mathrm{~b}$ \\
\hline \multirow[t]{3}{*}{ Significance $^{\mathrm{x}}$} & Scion & NS & NS & $* * *$ & $*$ \\
\hline & Rootstock & NS & NS & $*$ & $* *$ \\
\hline & Interaction & NS & NS & $* *$ & $* * *$ \\
\hline
\end{tabular}

z $\mathrm{G}$ and Mx indicate 'Gourmet' and 'Maxifort' of Dutch cultivars, respectively; My and S indicate 'Momotaro York' and 'Spike 23' of Japanese cultivars, respectively.

y Measured at $1000 \mu \mathrm{mol} \cdot \mathrm{mol}^{-1} \mathrm{CO}_{2}, 1500 \mu \mathrm{mol} \cdot \mathrm{m}^{-2} \cdot \mathrm{s}^{-1}$ PPFD.

${ }^{x} \mathrm{NS}, *$ **, and *** indicate not significant or significant at $P<0.05, P<0.01$, and $P<0.001$, respectively, by ANOVA $(\mathrm{n}=13-14)$

${ }^{\text {w }}$ Values within a column followed by different letters differ significantly at $P<0.05$ by Tukey's multiplecomparison test. 
119 DAT $(P<0.05$ or $P<0.01$, respectively). However, significant interaction effects of scion $\times$ rootstock were found on the conductance at 57 and 119 DAT $(P<0.01$ or $P<0.001$, respectively). My $/ \mathrm{S}$ had significantly $(P<$ 0.05 ) higher conductance than My/My at 57 DAT. At 119 DAT, there was no significant difference in the conductance of $\mathrm{G}$ scions among the rootstocks, but $\mathrm{My} / \mathrm{S}$ had significantly $(P<0.01)$ lower conductance than the other My scions (My/Mx and My/My). On the basis of these results, the rootstocks did not appear to influence the maximum (potential) photosynthetic rate. However, the stomatal conductance in My scions differed significantly among the rootstocks at both 57 and 119 DAT.

As there were significant differences among the scions $(P<0.01), \mathrm{G}$ scions had a significantly higher number of leaves, stem length, DW of fruits and stem, and total aboveground DM (TDM) than My scions (Table 2). There was neither a significant difference among the rootstocks nor an interaction effect of scion $\times$ rootstocks in any of these growth parameters at 63 DAT. Among G scions, leaf DW (LDW) was significantly $(P<0.01)$ higher in $\mathrm{G} / \mathrm{Mx}$ than in $\mathrm{G} / \mathrm{S}$ and $\mathrm{G} / \mathrm{G}$. Similarly, there was no significant difference among the rootstocks in these growth parameters for each scion at 92 DAT (data not shown), except for LDW and LAI; LDW and LAI was significantly $(P<0.01)$ higher for plants of each scion grafted onto $\mathrm{Mx}$ than self-grafts $(\mathrm{G} / \mathrm{G}$ and $\mathrm{My} / \mathrm{My})$.

Table 3 also shows significant $(P<0.001)$ differences among the scions in several growth parameters at 126 DAT (end of the experiment). G scions had a significantly higher number of leaves, stem length, and cumulative $\mathrm{DM}$ allocation to the fruits than My scions, but $\mathrm{G}$ scions had significantly lower LAI and LDW than My scions. There were significant $(P<0.05)$ differences between the rootstocks (Mx, S, and self-grafts) in LAI, LDW, or TDM, and a significant $(P<0.05)$ interaction effect of scion $\times$ rootstock on stem length. For each scion, there was no significant difference among the rootstocks in the

Table 2. Number of leaves, stem length, leaf area index (LAI), specific leaf area (SLA), and dry weight (DW) of fruits, leaves, and stems, and total aboveground dry matter (DM) in tomato plants reciprocally grafted between Dutch and Japanese cultivars at 63 days after transplanting.

\begin{tabular}{|c|c|c|c|c|c|c|c|c|c|}
\hline \multicolumn{2}{|c|}{ Scion/rootstock ${ }^{2}$} & $\begin{array}{c}\text { No. leaves } \\
\text { (leaves per plant) }\end{array}$ & $\begin{array}{c}\text { Stem length } \\
(\mathrm{cm} \text { per plant })\end{array}$ & $\begin{array}{c}\text { LAI } \\
\left(\mathrm{m}^{2} \cdot \mathrm{m}^{-2}\right)\end{array}$ & $\begin{array}{c}\text { SLA } \\
\left(\mathrm{cm}^{2} \cdot \mathrm{g}^{-1}\right)\end{array}$ & $\begin{array}{l}\text { Fruit DW } \\
\text { (g per plant) }\end{array}$ & $\begin{array}{l}\text { Leaf DW } \\
\text { (g per plant) }\end{array}$ & $\begin{array}{c}\text { Stem DW } \\
\text { (g per plant) }\end{array}$ & $\begin{array}{c}\text { Total DM } \\
\left(\mathrm{g} \cdot \mathrm{m}^{-2}\right)\end{array}$ \\
\hline \multicolumn{2}{|c|}{$\mathrm{G} / \mathrm{Mx}$} & 26.2 & 203 & 3.9 & 0.024 & 25.5 & $66.6 b^{x}$ & 38.5 & 322.7 \\
\hline \multicolumn{2}{|c|}{$\mathrm{G} / \mathrm{S}$} & 28.2 & 205 & 3.4 & 0.025 & 28.7 & $55.5 \mathrm{a}$ & 36.6 & 298.6 \\
\hline \multicolumn{2}{|c|}{$\mathrm{G} / \mathrm{G}$} & 26.8 & 207 & 3.2 & 0.023 & 28.6 & $56.1 \mathrm{a}$ & 37.4 & 301.8 \\
\hline \multicolumn{2}{|c|}{$\mathrm{My} / \mathrm{Mx}$} & 23.2 & 165 & 4.4 & 0.026 & 13.1 & $68.7 \mathrm{~A}$ & 29.2 & 274.5 \\
\hline \multicolumn{2}{|c|}{$\mathrm{My} / \mathrm{S}$} & 23.0 & 176 & 4.1 & 0.028 & 17.6 & $60.2 \mathrm{~A}$ & 28.6 & 263.1 \\
\hline \multicolumn{2}{|c|}{ My/My } & 23.8 & 179 & 3.5 & 0.023 & 19.2 & $61.0 \mathrm{~A}$ & 30.1 & 272.8 \\
\hline \multirow[t]{3}{*}{ Significance ${ }^{y}$} & Scion & $* * *$ & $* * *$ & NS & NS & $* * *$ & NS & $* * *$ & $* *$ \\
\hline & Rootstock & NS & NS & NS & NS & NS & $* *$ & NS & NS \\
\hline & Interaction & NS & NS & NS & NS & NS & NS & NS & NS \\
\hline
\end{tabular}

${ }^{z} \mathrm{G}$ and Mx indicate 'Gourmet' and 'Maxifort' of Dutch cultivars, respectively; My and S indicate 'Momotaro York' and 'Spike 23' of Japanese cultivars, respectively.

y NS, **, and *** indicate not significant or significant at $P<0.01$, and $P<0.001$, respectively, by ANOVA $(\mathrm{n}=6)$.

${ }^{x}$ Values within a column followed by different letters differ significantly for the same scion-cultivar at $P<0.05$ by Bonferroni post-hoc test.

Table 3. Number of leaves, stem length, leaf area index (LAI), specific leaf area (SLA), dry weight (DW) of leaves and stems, and total aboveground dry matter (DM), and cumulative DM allocation to the fruits in tomato plants reciprocally grafted between Dutch and Japanese cultivars at 126 days after transplanting.

\begin{tabular}{|c|c|c|c|c|c|c|c|c|c|}
\hline \multicolumn{2}{|c|}{ Scion/rootstock ${ }^{z}$} & $\begin{array}{c}\text { No. leaves } \\
\text { (leaves per plant) }\end{array}$ & $\begin{array}{l}\text { Stem length } \\
\text { (cm per plant) }\end{array}$ & $\begin{array}{c}\text { LAI } \\
\left(\mathrm{m}^{2} \cdot \mathrm{m}^{-2}\right)\end{array}$ & $\begin{array}{c}\text { SLA } \\
\left(\mathrm{m}^{2} \cdot \mathrm{g}^{-1}\right)\end{array}$ & $\begin{array}{l}\text { Leaf DW } \\
\text { (g per plant) }\end{array}$ & $\begin{array}{l}\text { Stem DW } \\
\text { (g per plant) }\end{array}$ & $\begin{array}{c}\text { Total DM } \\
\left(\mathrm{g} \cdot \mathrm{m}^{-2}\right)\end{array}$ & $\begin{array}{c}\text { DM allocation } \\
\text { to the fruits } \\
\left(\mathrm{g} \cdot \mathrm{g}^{-1}\right)\end{array}$ \\
\hline \multicolumn{2}{|c|}{$\mathrm{G} / \mathrm{Mx}$} & 51.5 & 447 & $5.4 \mathrm{a}^{\mathrm{x}}$ & 0.019 & $113 \mathrm{~b}$ & 84 & $1006 \mathrm{~b}$ & 0.52 \\
\hline \multicolumn{2}{|c|}{$\mathrm{G} / \mathrm{S}$} & 49.8 & 428 & $4.4 \mathrm{a}$ & 0.020 & $92 \mathrm{a}$ & 74 & $837 \mathrm{a}$ & 0.50 \\
\hline \multicolumn{2}{|c|}{$\mathrm{G} / \mathrm{G}$} & 51.1 & 444 & $4.9 \mathrm{a}$ & 0.020 & $98 \mathrm{ab}$ & 84 & $949 \mathrm{ab}$ & 0.53 \\
\hline \multicolumn{2}{|c|}{$\mathrm{My} / \mathrm{Mx}$} & 45.1 & 363 & $7.0 \mathrm{~B}$ & 0.020 & $145 \mathrm{~B}$ & 82 & $966 \mathrm{~A}$ & 0.41 \\
\hline \multicolumn{2}{|c|}{$\mathrm{My} / \mathrm{S}$} & 44.5 & 371 & $6.5 \mathrm{AB}$ & 0.021 & $127 \mathrm{AB}$ & 84 & $884 \mathrm{~A}$ & 0.41 \\
\hline \multicolumn{2}{|c|}{ My/My } & 43.5 & 349 & $5.9 \mathrm{~A}$ & 0.020 & $123 \mathrm{~A}$ & 84 & $821 \mathrm{~A}$ & 0.38 \\
\hline \multirow[t]{3}{*}{ Significance ${ }^{y}$} & Scion & $* * *$ & $* * *$ & $* * *$ & NS & $* * *$ & NS & NS & $* * *$ \\
\hline & Rootstock & NS & NS & $*$ & NS & $* *$ & NS & $*$ & NS \\
\hline & Interaction & NS & $*$ & NS & NS & NS & NS & NS & NS \\
\hline
\end{tabular}

${ }^{\text {z }} \mathrm{G}$ and Mx indicate 'Gourmet' and 'Maxifort' of Dutch cultivars, respectively; My and S indicate 'Momotaro York' and 'Spike 23' of Japanese cultivars, respectively.

y $\mathrm{NS}, *, * *$, and $* * *$ indicate not significant or significant at $P<0.05, P<0.01$, and $P<0.001$, respectively, by ANOVA (n=12).

${ }^{x}$ Values within a column followed by different letters significantly differ for the same scion-cultivar at $P<0.05$ by Bonferroni post-hoc test. 
number of leaves, stem length, specific leaf area (SLA), stem DW, and DM allocation to the fruits. G/Mx was significantly $(P<0.01)$ higher in LDW than $\mathrm{G} / \mathrm{S}$. Among My scions, My/Mx had significantly $(P<0.05$ and $P<$ 0.01 ) higher LAI and LDW than My/My. G/Mx had significantly $(P<0.05)$ higher TDM than $\mathrm{G} / \mathrm{S}$.

$\mathrm{G} / \mathrm{S}$ had significantly lower LUE than $\mathrm{G} / \mathrm{Mx}$ and G/G (Fig. 4). Among the combinations with My scions, there was no significant difference in LUE. The lightextinction coefficient was significantly lower in My scions than in $\mathrm{G}$ scions except for My/Mx. Among G scions, $\mathrm{G} / \mathrm{S}$ had a significantly higher coefficient than $\mathrm{G} / \mathrm{Mx}$ and G/G. Among My scions, My/My had a significantly lower coefficient than $\mathrm{My} / \mathrm{Mx}$ and $\mathrm{My} / \mathrm{S}$.

Table 4 shows the correlations among the various yield components in each scion; $\mathrm{G}$ scions $(\mathrm{G} / \mathrm{Mx}, \mathrm{G} / \mathrm{S}$, and $\mathrm{G} / \mathrm{G}$ ) and My scions (My/Mx, My/S, and My/My). For both scions, the fruit fresh weight yield per unit area was significantly positively and highly $(r=0.96-0.97, P$ $<0.001)$ correlated with the fruit DW yield per unit area. Although the fruit fresh weight yield per unit area was significantly negatively and weakly $(r=-0.56, P<0.001)$ correlated with the fruit DM content in My scions, there was no significant correlation $(r=0.32, P=0.06)$ in $\mathrm{G}$ scions. For both scions, the fruit DW yield was significantly positively and highly $(r=0.71-0.96, P<0.001)$ correlated with TDM. The fruit DW yield per unit area

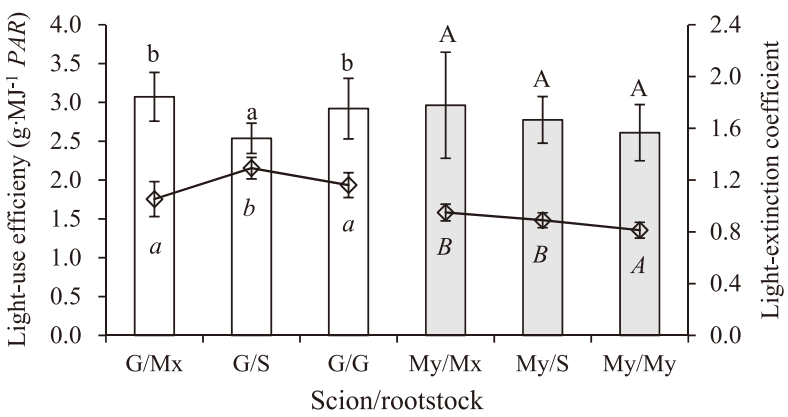

Fig. 4. Light-use efficiency (bars) and light-extinction coefficient (lines) in tomato plants reciprocally grafted between Dutch and Japanese cultivars at 126 and 65 DAT, respectively. Different letters differ significantly within the same scion-cultivar $(P<$ $0.05 ; \mathrm{n}=12$; by $95 \%$ confidence intervals). Vertical bars represent $95 \%$ confidence intervals. $\mathrm{G}$ and $\mathrm{Mx}$ indicate 'Gourmet' and 'Maxifort' of Dutch cultivars, respectively; My and S indicate 'Momotaro York' and 'Spike 23' of Japanese cultivars, respectively. was also significantly and positively $(r=0.52-0.75, P<$ 0.01 ) correlated with the cumulative DM allocation to the fruits in both scions.

Figure 5 shows the relationships among the various growth and photosynthetic characteristics of the scion/ rootstock combinations. There was a significant, positive, and high $(r=0.98, P<0.001)$ correlation between LUE and TDM (Fig. 5A). However, there was no significant correlation between LUE and either the maximum photosynthetic rate or stomatal conductance (Fig. 5B, C). LUE was not correlated with the light-extinction coefficient ( $r=0.01, P=0.88)$. There was also no significant correlation $(r=0.02, P=0.97)$ between the maximum photosynthetic rate and stomatal conductance (Fig. 5D).

\section{Discussion}

Fruit fresh and dry weights per unit area of My (Japanese cultivar) grafted onto Mx (Dutch rootstock) were significantly and ca. 30\% higher than in My selfgrafts, but there was no significant difference in fruit DM content between the rootstocks ( $\mathrm{My} / \mathrm{Mx}$ and $\mathrm{My} / \mathrm{My}$; Figs. 2 and 3). Accordingly, for both G and My scions, the difference in fruit fresh weight yield per unit area among the rootstocks was mainly determined by the difference in fruit DW yield. There was a significant difference in TDM between the rootstocks but no difference in cumulative DM allocation to the fruits (Table 3). On the basis of Table 4, the fruit DW yield was related to both TDM and DM allocation to the fruits. DM allocation to the fruits generally increased with the harvesting period and reached a specific maximum value in each cultivar (Kahn and Sager, 1969; Scholberg et al., 2000). However, since the allocation $\left(0.38\right.$ to $0.53 \mathrm{~g} \cdot \mathrm{g}^{-1}$ according to the combinations, Table 3 ) did not reach the maximum value in each cultivar in this short-term experiment, DM allocation to the fruits was the primary influence on the yield. LUE and/or intercepted light may determine total DM production directly (Higashide and Heuvelink, 2009). There was little difference in intercepted PAR (data not shown). The increase in TDM was therefore determined by the increase in LUE (Fig. 5A). Although the increase in TDM was determined by the increase in LUE and not by intercepted PAR, we could not explain the cause of the increase in LUE based on our data. The maximum photosynthetic rate of individual leaves did not differ significantly between the rootstocks

Table 4. Correlation coefficients (Pearson's $r$ ) between yield components in Dutch ('Gourmet') or Japanese ('Momotaro York') tomato scion cultivars with different rootstocks ('Maxifort', 'Spike 23', self-grafts) at 126 days after transplanting.

\begin{tabular}{llcccc}
\hline \hline \multirow{2}{*}{ Scion } & & $\begin{array}{c}\text { Fruit DW yield } \\
\text { per unit area }\end{array}$ & $\begin{array}{c}\text { Fruit dry matter } \\
\text { content }\end{array}$ & $\begin{array}{c}\text { Total aboveground } \\
\text { dry matter }\end{array}$ & $\begin{array}{c}\text { Dry matter allocation } \\
\text { to the fruits }\end{array}$ \\
\hline \multirow{2}{*}{ 'Gourmet' } & FW yield per unit area & \multirow{2}{*}{$0.97^{* * *}$} & $0.32 \mathrm{NS}$ & $0.93 * * *$ & $0.50 * *$ \\
& DW yield per unit area & & $0.52 * *$ & $0.96^{* * *}$ & $0.52^{* * *}$ \\
\hline \multirow{2}{*}{ 'Momotaro York' } & FW yield per unit area & \multirow{2}{*}{$0.96^{* * *}$} & $-0.56 * * *$ & $0.56^{* * *}$ & $0.83^{* * *}$ \\
& DW yield per unit area & & $-0.34 *$ & $0.71^{* * *}$ & $0.75^{* * *}$ \\
\hline
\end{tabular}

FW yield, yield of fruits (fresh weight per unit area); DW yield, yield of fruits (dry weight per unit area).

NS indicates non-significant; ${ }^{*}, * *$, and $* * *$ indicate a significant correlation at $P<0.05,0.01$, and 0.001 , respectively $(\mathrm{n}=36)$. 

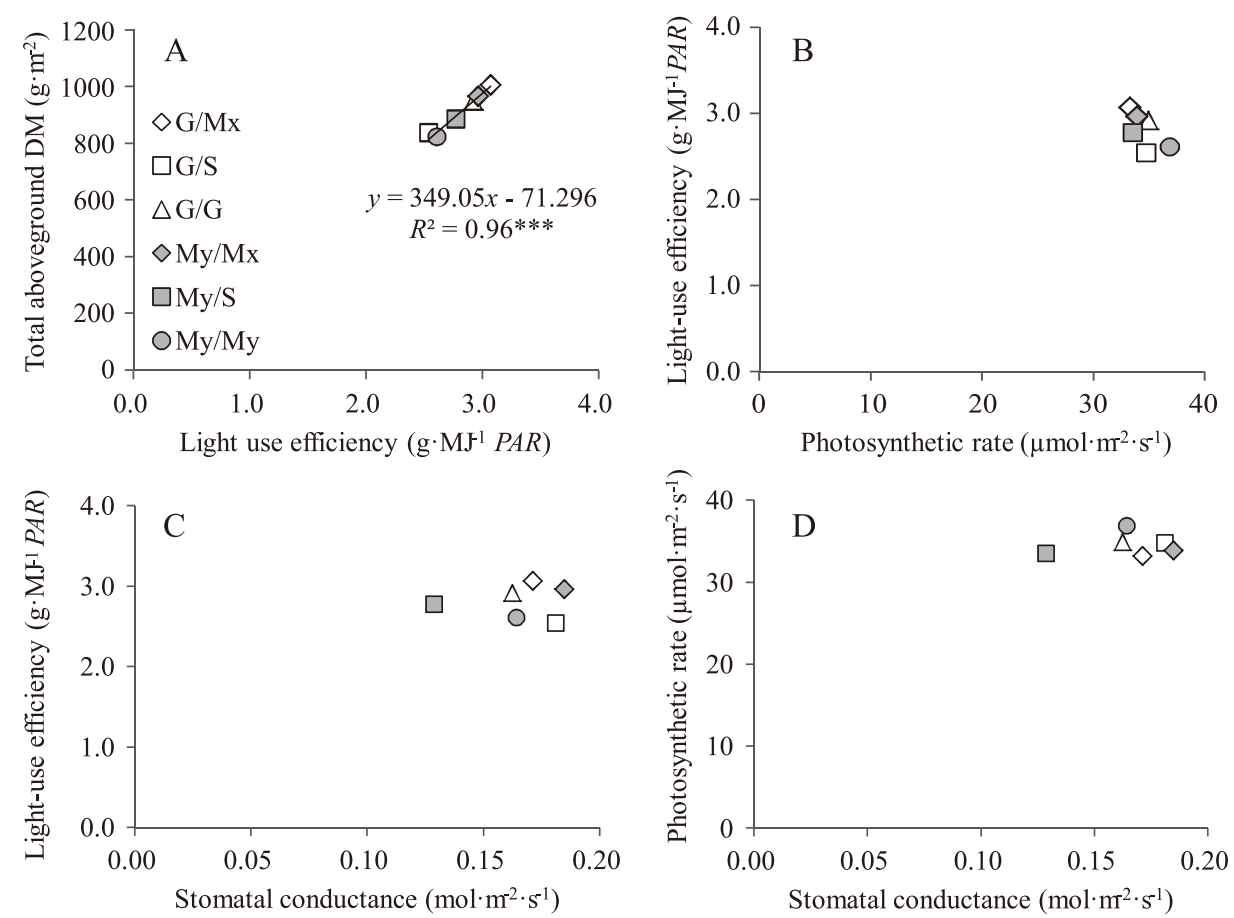

Fig. 5. Relationships between the growth and photosynthetic characteristics: between total aboveground dry matter (DM) and light-use efficiency (A); between light-use efficiency and maximum photosynthetic rate (B); between light-use efficiency and stomatal conductance (C); and between maximum photosynthetic rate and stomatal conductance (D). G and Mx indicate 'Gourmet' and 'Maxifort' of Dutch cultivars, respectively; My and S indicate 'Momotaro York' and 'Spike 23' of Japanese cultivars, respectively; slashes between the cultivars shows grafting, scion/rootstock. *** indicates a significant correlation at $P<0.001$.

(Table 1). There was no significant correlation between the maximum photosynthetic rate and LUE (Fig. 5B). This result did not coincide with previous reports in which the increase in LUE was caused by the increase in the leaf photosynthetic rate (Higashide and Heuvelink, 2009; Higashide et al., 2012). The results of LUE and the light-extinction coefficient (Fig. 4) coincided with a previous report on Dutch cultivars, in which LUE was affected by the light-extinction coefficient and increased with a decreasing coefficient (Higashide and Heuvelink, 2009), and with a report on Japanese cultivars in which these relationships between LUE and the light-extinction coefficient were not observed (Higashide et al., 2012).

Di Gioia et al. (2010) reported that leaf weight and area, and fruit yield increased in heirloom tomato varieties grafted onto Mx. Similarly, we found that LDW and LAI increased in both Dutch and Japanese scions grafted onto Mx (Tables 2 and 3). DM allocation to the leaves (LDW/TDM) at $126 \mathrm{DAT}$ ranged from 0.35 to $0.37 \mathrm{~g} \cdot \mathrm{g}^{-1}$ in My scions, and from 0.26 to $0.28 \mathrm{~g} \cdot \mathrm{g}^{-1}$ in $\mathrm{G}$ scions. Although DM allocation to the leaves was significantly $(P<0.001)$ higher than in $\mathrm{G}$ scions, there was no significant difference in SLA (Tables 2 and 3 ) and in $\mathrm{DM}$ allocation to the leaves among the rootstocks $(\mathrm{Mx}$, $\mathrm{S}$, and self-grafts) for each scion. This suggests that the increases in LDW and leaf area were mainly determined by the increase in TDM.

Downregulation of the photosynthetic rate is caused by feedback between carbon metabolite levels and photosynthesis (Paul and Pellny, 2003). Thus, downregulation of photosynthetic rates could be caused by an accumulation of photoassimilates in the leaves, because the sink strength then becomes lower than the source strength (Arp, 1991). For grafted sweet potato, Hojo and Park (1971) reported that the decrease in photoassimilate utilization resulted in the decrease in sink strength of the roots of sweet potato caused photoassimilate accumulation in the leaves, which then decreased the individualleaf photosynthetic rate. In our experiments on grafted tomatoes, Table 1 reveals no downregulation of the maximum photosynthetic rate of self-grafts (My/My), which showed lower yield and LUE. This result was also supported by the lack of a significant difference in TDM at 63 (Table 2) or 92 DAT (data not shown). Accordingly, the Japanese tomato scions did not appear to cause downregulation of the individual-leaf photosynthetic rate, and the grafting of $\mathrm{My} / \mathrm{Mx}$ did not appear to improve the maximum photosynthetic rate of the Japanese scions.

Furukawa et al. (2010) reported that the permeability of the roots of tomato seedlings to the nutrient solution was higher in a Japanese cultivar than in a Dutch cultivar. Mohammed et al. (2009) reported increases in the $\mathrm{Ca}, \mathrm{Na}, \mathrm{Mg}, \mathrm{Fe}$, and $\mathrm{K}$ contents in tomato leaves caused by grafting. Oda et al. (1996) reported that grafting onto Solanum integrifolium increased the chlorophyll content of tomato leaves and increased the soluble solids content in the fruits, but decreased the fruit fresh-weight yield, and that these changes potentially resulted from plant 
water stress. These reports suggest that the rootstocks might influence plant water relations, thereby indirectly affecting stomatal conductance. In our experiments, stomatal conductance was lower at 119 DAT than at 57 DAT in all scion/rootstock combinations, and stomatal conductance in the Japanese scions differed significantly among the rootstocks at both 57 and 119 DAT (Table 1). However, the maximum photosynthetic rate was not influenced by stomatal conductance (Table 1; Fig. 5D), as in the report by Gosiewski et al. (1982). It remains unclear whether Mx as the rootstock contributes to the improvement of stomatal conductance and then DM production of the Japanese cultivar.

Based on the present results, we conclude that the fruit yield would be improved by grafting Japanese scion 'Momotaro York' onto Dutch rootstock 'Maxifort'. We also presumed that the Mx rootstock increased LUE of the Japanese cultivar My, leading to increased TDM and fruit DW yield. The rootstocks did not influence the maximum photosynthetic rate of individual leaves in both scions, although stomatal conductance differed among the rootstocks in the Japanese scions at both 57 and 119 DAT. However, since DM production per plant is determined by the sum of DM production by individual leaves, the difference in TDM must be caused by differences in DM production by individual leaves. Although we measured the maximum photosynthetic rate of 2 matured leaves per plant, the plants had not only these 2 leaves but also many others. Moreover, the actual photosynthetic rate of the leaves (despite a lack of significant difference in the maximum photosynthetic rate) might respond differently depending on the environmental conditions. In order to determine the cause of differences by the rootstocks in DM production and LUE, and to confirm whether stomatal conductance influences the actual photosynthetic rate and then DM production, it will be necessary to monitor stomatal conductance, the actual photosynthetic rate, and plant water stress simultaneously.

\section{Literature Cited}

Arp, W. J. 1991. Effects of source-sink relations on photosynthetic acclimation to elevated $\mathrm{CO}_{2}$. Plant Cell Environ. 14: 869-875.

Di Gioia, F., F. Serio, D. Buttaro, O. Ayala and P. Santamaria. 2010. Influence of rootstock on vegetative growth, fruit yield and quality in 'Cuore di Bue', an heirloom tomato. J. Hort. Sci. Biotech. 85: 477-482.

Fan, M., Z. Bie, A. Krumbein and D. Schwarz. 2011. Salinity stress in tomatoes can be alleviated by grafting and potassium depending on the rootstock and K-concentration employed. Sci. Hortic. 130: 615-623.

Flores, F. B., P. Sanchez-Bel1, M. T. Estañ, M. M. MartinezRodriguez, E. Moyano, B. Morales, J. F. Campos, J. O. GarciaAbellán, M. I. Egea, N. Fernández-Garcia, F. Romojaro and M. C. Bolarín. 2010. The effectiveness of grafting to improve tomato fruit quality. Sci. Hortic. 125: 211-217.

Furukawa, T., K. Ishikawa, S. Onuki, K. Mukai and T. Ikeda. 2010. Permeability of root cells of Dutch 'Dundee' and Japanese 'Reiyo' varieties of tomato seedlings to hydroponic solution and potassium ions. J. Japan. Soc. Hort. Sci. 79: 287-293.
Gosiewski, W., H. J. M. Nilwik and J. F. Bierhuizen. 1982. The influence of temperature on photosynthesis of different tomato genotypes. Sci. Hortic. 16: 109-115.

Higashide, T. and E. Heuvelink. 2009. Physiological and morphological changes over the past 50 years in yield components in tomato. J. Amer. Soc. Hort. Sci. 134: 460-465.

Higashide, T., K. Yasuba, K. Suzuki, A. Nakano and H. Ohmori. 2012. Yield of Japanese tomato cultivars has been hampered by a breeding focus on flavor. HortScience 47: 1408-1410.

Hojo, Y. and C. Y. Park. 1971. Plant production in grafting plants between wild type and improved variety in Ipomoea. Bull. Natl. Inst. Agric. Sci. Series D. 22: 145-164 (In Japanese with English summary).

Jiang, D. A., T. Hirasawa and K. Ishihara. 1994. The difference of diurnal changes in photosynthesis in rice plants with different root activities induced by soluble starch application to the soil. Jpn. J. Crop Sci. 63: 539-545 (In Japanese with English summary).

Kahn, A. and G. R. Sager. 1969. Alteration of the pattern of distribution of photosynthetic products in the tomato by manipulation of the plant. Ann. Bot. 33: 753-762.

Khah, E. M., E. Kakava, A. Mavromatis, D. Chachalis and C. Goulas. 2006. Effect of grafting on growth and yield of tomato (Lycopersicon esculentum Mill.) in greenhouse and open-field. J. Appl. Hort. 8: 3-7.

Kubota, F., K. Iizuka and W. Agata. 1993. Photosynthetic control factors in a single leaf of sweet potato, Ipomoea batatas Lam. 2. Sink-source relationship between photosynthesis and root weight production in single leaf graft. Jpn. J. Crop Sci. 62: 248-256 (In Japanese with English summary).

Kurata, K. 1994. Light environmental control. p.233-242. In: S. Nishi, M. Amano, T. Itagi, T. Ito, I. Ueno, S. Okitsu, I. Kurata, T. Kozai, Y. Odaka, R. Sakiyama, K. Seike, T. Takakura, H. Hakura and T. Murai (eds.). Greenhouse horticulture handbook 3rd edition (In Japanese). Japan Greenhouse Horticulture Association, Tokyo.

Masuda, M. and S. Furusawa. 1991. Fruit yield and quality of tomatoes as affected by rootstocks in long-term nutrient film technique culture. Sci. Rep. Fac. Agric. Okayama Univ. 78: 17-25 (In Japanese with English summary).

Mohammed, S. T. M., M. Humidan, M. Boras and O. A. Abdalla. 2009. Effect of grafting tomato on different rootstocks on growth and productivity under glasshouse conditions. Asian J. Agric. Res. 3: 47-54.

Monsi, M. and T. Saeki. 2005. On the factor light in plant communities and its importance for matter production. Ann. Bot. 95: 549-567 (Über den Lichtfaktor in den Pflanzengesellschaften und seine Bedeutung für die Stoffproduction. Jap. J. Bot. 14: 22-52).

Oda, M., M. Nagata, K. Tsuji and H. Sasaki. 1996. Effects of scarlet eggplant rootstock on growth, yield, and sugar content of grafted tomato fruits. J. Japan. Soc. Hort. Sci. 65: 531-536.

Ohtani, Y. 1997. Effective radiation, micrometeorological phenomena. p. 106-107. In: T. Maki, S. Iwata, Z. Uchijima, T. Oikawa, K. Omasa, K. Kurata, T. Kozai, E. Goto, H. Kon, I. Nouchi, Y. Harazono, T. Hoshi, H. Honjo and S. Yamakawa (eds.). Agricultural meteorology glossary (In Japanese). Society for Agricultural Meteorology of Japan, Tokyo.

Paul, M. J. and T. K. Pellny. 2003. Carbon metabolite feedback regulation of leaf photosynthesis and development. J. Exp. Bot. 54: 539-547.

Sada, A. 1981. Effect of grafting on the growth and yield of tomato under semi-forcing culture. Bull. Wakayama Agric. Exp. Stn. 8: 31-38 (In Japanese with English summary).

Savvas, D., A. Savva, G. Ntatsi, A. Ropokis, I. Karapanos, A. 
Krumbein and C. Olympios. 2011. Effects of three commercial rootstocks on mineral nutrition, fruit yield, and quality of salinized tomato. J. Plant Nutr. Soil Sci. 174: 154-162.

Scholberg, J., B. L. McNeal, J. W. Jones, K. J. Boote, C. D. Stanley, and T. A. Obreza. 2000. Growth and canopy characteristics of field-grown tomato. Agron. J. 92: 152-159.

Shishido, Y. and H. Kumakura. 1994. Effects of root temperature on photosynthesis, transpiration, translocation and distribution of ${ }^{14} \mathrm{C}$-photoassimilates and root respiration in tomato. J. Japan. Soc. Hort. Sci. 63: 81-89 (In Japanese with English summary).

Tanaka, A. and K. Fujita. 1972. Studies on the fruit production of tomato plants on the basis of the source-sink theory (Part 3). Jpn. J. Soil Sci. Plant Nutr. 43: 423-428 (In Japanese with English summary).

Turkmen, O., M. Seymen and A. Dursun. 2010. Effects of different rootstocks and cultivars on yield and some yield components of grafted tomato. Bull. Univ. Agric. Sci. Vet. Med. ClujNapoca Hortic. 67: 284-291. 